\title{
RISK FACTORS ASSOCIATED WITH PRETERM LABOR
}

\author{
Prof. Sanaa Aly Nour; Dr. Manar Fathy Heiba; Rasha Awad Zaki Ali \\ Prof of Obstetric and Gynecology, Faculty of Nursing-Zagazig University, Lecturer \\ of Maternity, Obstetric and Gynecological Nursing, Faculty of Nursing - Portsaid \\ University, Faculty of Nursing - Alexandria \\ University
}

\begin{abstract}
Objectives: The aim of this study was to determine the risk factors associated with preterm labor. Subject and Methods: A case- control design was selected in carrying out this study and a sample of 208 parturient women (104 with preterm labor being hospitalized or none hospitalized before delivery and 104 with normally vaginal delivery) were recruited for this study. The tools used for data collection were; an interview questionnaire and assessment sheet. Results: The results of this study revealed that $(37.5 \%)$ were nulligravida, $(39.4 \%)$ nulliparas, $(29.8 \%)$ have history of previous preterm labor, previous CS (41.5\%) and exposure to stress (71.2\%), violence (29.8) were all risk factors for PTL. Recommendations: the study recommended that early diagnosis of preterm labor, identification of risk factors, adopting recent modalities of diagnoses and management in appropriate setting and with adequate resources may help in better outcome by reducing the fetal-maternal complications. Conclusion: It was concluded that more than one third of PTL women were nulligravida and nullipara. Higher percentage of them was exposed to violence and stress, passive smoking, medical and gynecological problems. PTL had adverse effects on fetal birth outcome lower Apgar score, low birth weight.
\end{abstract}

Key words: Preterm Labor, Risk factors, Management. 


\section{INTRODUCTION}

Each year more than 536,000 women die from pregnancy related complications; about $99.0 \%$ of these reproductive linked deaths are reported in developing countries, often because women lack access to life-saving care. (WHO, 2010). A normal pregnancy lasts 37 to 42 weeks, counting from the first day of the last menstrual period. A pregnancy that continues beyond 37 weeks is called a "term" pregnancy. Preterm labor is defined as labor that begins before 37 weeks of pregnancy (Edmund et al., 2014).

Premature labor is one of the most common problems in pregnancy and it is the cause of 75 percent of all newborn deaths in babies born without birth defects. Preterm birth is the most important single determinant of adverse infant outcome, in terms of both survival and quality of life. Premature babies are more delicate and can have lifelong problems related to their prematurity (Society of Obstetricians and Gynecologists of Canada, 2013). Preterm labor is defined as the presence of uterine contractions of sufficient frequency and intensity which induce progressive effacement and dilation of the cervix prior to term gestation (between 20 and 37 week) (Chawan, 2010).

Approximately 12 percent of babies in the United States are born preterm; 80 percent of these are due to preterm labor that occurs on its own or after preterm premature rupture of the fetal membranes or "broken bag of waters". The remaining 20 percent are planned early deliveries that are done for maternal or fetal problems that prevent the woman from being able to safely continue with her pregnancy (Edmund et al., 2014).

In fact, the cause of $50 \%$ of preterm births is never determined. About $40-50 \%$ of all preterm labor can be traced to infection and bleeding that resulted from placenta abruption or placenta previa where the placenta tears away from the uterine wall too early (Robert, 2007). Chronic illnesses as high blood pressure and diabetes may also cause preterm birth (National Premmie Foundation, 2014).

The nurse plays an important role in reducing the risk of morbidity and mortality and restoring the mother and her baby to good health. The Nurse's priorities include greeting the patient, giving good supportive care, talking about the importance of supportive care, reassuring the mother to lessen their fear and accept the patient's behavior under stress without signs of disapproval, providing information about emotional changes that occur during pregnancy, monitoring the progress of labor and providing support toward any psychosocial or psychological problems (Simhan, 2007).

Maternity nurses have a responsibility to provide women's holistic health care. Risk assessment and management of preterm labor is a very important aspect of holistic health care, which needs to be promoted. The nurse midwife in particular can play a crucial role 
as case finder, educator and counselor regarding preterm labor and its management (Ricci \& Kyle, 2009).

\section{Significance of the Problem:}

Preterm birth is responsible for three-quarters of cases of neonatal mortality and onehalf of cases of neurologic impairment in children (Sanu, 2011). The risk of longterm neurodevelopment and medical disabilities is high among children born preterm (Sayres WG). Gestational age is inversely proportional to the risk of neonatal morbidity and mortality (ACOG Committee on Practice Bulletins, 2003). Infant mortality is significantly higher among neonates born before 32 weeks' gestation than in those born later (Sayres, 2010). Birth prior to 32 weeks' gestation causes the most neonatal deaths and the most long-term morbidity. However, neonates born between 34 and 36 weeks' gestation constitute the majority of Neonatal Intensive Care Unit (NICU) admissions.

Despite advances in obstetric and neonatal care, the incidence of preterm birth continues to increase. The rate of preterm birth has risen $20 \%$ in the last two decades, with most births occurring between 34 and 36 weeks' gestation. This may be partly due to greater numbers of indicated preterm births attributed to maternal conditions and of multiple gestations following assisted conception (Denney, 2008), so this study was done to look for factors responsible for rising rates of preterm labor and consequent mortality and morbidity. This would enable nursing staff to improve intervention strategies concerned with this high risk cause of neonatal death The estimated incidence of preterm labor in Belqas general hospital was 33\%, 44\%, 23\% reported in 2010, 2011, 2012 respectively (Statistical Health Department 2010, 2011, 2012). The present study is conducted to shed light on the risk factors associated with preterm labor

\section{AIM OF STUDY:}

The aim of this study is to determine risk factors associated with preterm labor.

\section{Research Questions:}

1. What are the risk factors associated with preterm labor?

2. What are the consequences of preterm labor?

\section{SUBJECT AND METHODS:}

A case-control design was utilized in this study to determine the risk factors associated with preterm labor and compare between women with preterm labor and those with normal labor. The subjects consisted of $\mathbf{2 0 8}$ women, they were studied according to the following criteria. Diagnosed with preterm labor (104), Women at age ranged between 18 to 40 years of age.,Those who had spontaneous delivery (104),On admission to labor room.

A consecutive sample of women fulfilling the foregoing criteria was recruited from the study setting until the required sample size (208) was obtained. Structured interview form was developed and modified by the researcher based on (Dobson, A.J., 2002)assessment screen questionnaire. 


\section{The questionnaire consisted of five parts as the following:}

The First Part: This part included Socio-demographic data such as age, education, occupation, religion, residence, marital status, size of the family, family income and housing condition.

The Second Part: This part included Medical history of the patient; diabetes, hypertension, renal disease.

The Third Part: This part included data about obstetrical history such as: gravidity, parity, previous abortion, number of living children, Spacing between present and previous pregnancy, low birth weight and history of multiple pregnancy as well as the current pregnancy history.

The Fourth Part: This part included Life style and sexual factors such as: rest, sleep, exercise, nutrition relaxation, smoking, long working hours, violence, late or no prenatal care and sexual pattern.

The Fifth Part: This part included data outcome of labor and neonatal condition by evaluation of Apgar scores at first and fifth minute, birth weight

\section{Content Validity:}

After the tool had been designed, it was tested for its validity and reliability. Then the pilot study was carried out on $10 \%$ of the sample in the study setting that were excluded from the study sample. The purposes of the pilot study were to test the applicability and clarify the feasibility of the study tools and it served to estimate the time needed to complete the tools. It also helped to find out any obstacles and problems that might interfere with data collection, based on findings of the pilot study, certain modification of the tools were done. Subjects included in the pilot study were excluded from the study subjects. Following this pilot study, the process of data collection was performed.

\section{RESULTS}

Table 1 presents the number and percent distribution of the studied women according to their socio-demographic characteristics. As regards age, it was observed that women who had preterm labor were more likely to be younger than 20 years and older than 30 years of age compared to those in the control group $(19.2 \%, 20.2 \%$ vs. $6.7 \%, 17.3 \%$ ) with a mean of $25.97 \pm 6.1$ vs. $26.45 \pm 4.76$. Differences observed are statistically significant $\left(\mathrm{t}=.640\right.$ and $\left.0.523^{*}\right)$.

Meanwhile, both groups had similar levels of education and the majority were housewives and living in rural areas. As for the family income, women in the study group had lesser income that just meet their life expenses compared to the control group (64.4\% vs. $76.9 \%$ respectively). The difference observed is statistically significant $(\mathrm{p}=0.048)$.

Table 2 Concerning women's obstetrical history table 2 shows that more than one third (37.5\% \& 39.4\%) of PTL women were nulligravida and nulliparas compared to only $13.5 \% \& 16.3 \%$ in the control group. The difference observed is statistically significant 
$(\mathrm{P}<0.001)$. As for the history of previous abortion, it was present in more than two fifth of the two groups ( $46.2 \%$ vs. $41.3 \%$ respectively). Moreover, women in the study group were more likely to have no children (40.4\%) compared to those in the control group $(16.3 \%)$ with a statistical significant difference $(\mathrm{P}<0.001)$.

Figure 1 shows that women in the PTL group were more likely to have history of PTL and previous CS of the last delivery compared to those in the control group $(41.5 \%, 29.8 \%$ vs. $1.5 \%, 1.9 \%$ respectively). The differences observed are statistically significant $(\mathrm{P}<0.001)$.

Table 3 shows that, the percentage of passive smoking was significantly higher in women with PTL (67.3\% vs. 53.8\%), than the control group $\left(X^{2}=3.946, p=0.047\right)$. Furthermore, they were more likely to have excessive intake of coffee or tea compared to the control group $(65.4 \%$ vs. $57.7 \%$ respectively). Also, higher percentage of them were exposed to violence and stress in contrast to women with normal vaginal delivery $(29.8 \%, 71.2 \%$ vs. $20.2 \%, 39.4 \%$ respectively).

Table 5 shows that the occurrence of medical and gynecological problems was significantly higher $\left(\mathbf{X}^{2}=7.917, \mathrm{p}=0.005\right)$ in women with (PTL) than women with normal vaginal delivery $(35.6 \%$, versus $18.3 \%)$. The most common problem was preeclampsia $(23.1 \%$ vs. $1.0 \%)$ followed by vaginal infection $(16.3 \%$ vs. $8.7 \%$ respectively). The differences observed are statistically significant $(\mathrm{P}=<0.001 *$ \& $0.043 *)$.

Figure 2 Shows that hemoglobin level was higher in women with normal vaginal delivery than women in the preterm labor group ( $9.6 \pm 0.7$ vs. $10.2 \pm 0.7$ respectively).

Table 6 Show that women in the (PTL) group had lesser labor pain than the control group $(48.1 \%$ vs. $91.3 \%$ respectively). However, they were more likely to have premature rupture of membranes, vaginal bleeding and preeclampsia compared to those in the control group $(63.5 \%, 11.5 \% \& 19.2 \%$ vs. $30.8 \%, 0.9 \% \& 0.9 \%$ respectively). Moreover, $8.6 \%$ felt the gush of watery fluid compared to none in the control group. Differences observed are statistically significant $\left(\mathrm{P}=<0.001^{*}\right)$

Table (9) demonstrates significantly lesser mean Apgar scores at the first and fifth minutes in the study group ( $\mathrm{p}=0.000$ ). Thus, at the first minute it was $4.4 \pm 0.7$ vs. $5.9 \pm 0.7$ and at the fifth minute it was $6.2 \pm 7.9$. The same pattern was also noticed in the birth weight, with a lesser mean birth weight in PTL than the control group $(1.4 \pm 0.9$ vs. $2.9 \pm 0.4$ respectively). Differences observed are statistically significant $(\mathrm{p}=0.000)$. 
Table 1: Distribution of the Studied Women According to their Socio-demographic Characteristics $(\mathrm{n}=208)$

\begin{tabular}{|c|c|c|c|c|c|c|}
\hline \multirow[t]{2}{*}{$\begin{array}{l}\text { Socio-demographic } \\
\text { characteristics }\end{array}$} & \multicolumn{2}{|c|}{$\begin{array}{l}\text { Patients (PTL) } \\
(n=104)\end{array}$} & \multicolumn{2}{|c|}{$\begin{array}{l}\text { Control } \\
(\mathrm{n}=104)\end{array}$} & \multirow[t]{2}{*}{$\mathbf{X}^{2}$} & \multirow[t]{2}{*}{$\mathbf{P}$} \\
\hline & No & $\%$ & No & $\%$ & & \\
\hline $\begin{array}{l}\text { Age (years) } \\
<20 \\
20-30 \\
>30 \\
\end{array}$ & $\begin{array}{l}20 \\
63 \\
21\end{array}$ & $\begin{array}{l}19.2 \\
60.6 \\
20.2\end{array}$ & $\begin{array}{l}7 \\
79 \\
18 \\
\end{array}$ & $\begin{array}{l}6.7 \\
76 \\
17.3 \\
\end{array}$ & 8.293 & $0.016^{*}$ \\
\hline Mean \pm SD & \multicolumn{2}{|c|}{$25.97 \pm 6.01$} & \multicolumn{2}{|c|}{$26.45 \pm 4.76$} & $t=0.640$ & $0.523 *$ \\
\hline $\begin{array}{l}\text { Education level } \\
\text { Illiterate } \\
\text { write and read } \\
\text { basic education } \\
\text { Secondary education } \\
\text { University education }\end{array}$ & $\begin{array}{l}4 \\
7 \\
10 \\
52 \\
31\end{array}$ & $\begin{array}{l}3.8 \\
6.7 \\
9.7 \\
50.0 \\
29.8 \\
\end{array}$ & $\begin{array}{l}8 \\
8 \\
5 \\
49 \\
34 \\
\end{array}$ & \begin{tabular}{|l|}
7.7 \\
7.7 \\
4.8 \\
47.1 \\
32.7 \\
\end{tabular} & 4.961 & 0.421 \\
\hline $\begin{array}{l}\text { Occupation } \\
\text { Working } \\
\text { Not working }\end{array}$ & $\begin{array}{l}25 \\
79\end{array}$ & $\begin{array}{l}24.0 \\
76.0\end{array}$ & $\begin{array}{l}34 \\
70\end{array}$ & $\begin{array}{l}32.7 \\
67.3\end{array}$ & 1.917 & 0.166 \\
\hline $\begin{array}{l}\text { Family income } \\
\text { Just meet their life expenses } \\
\text { Not enough }\end{array}$ & $\begin{array}{l}67 \\
37\end{array}$ & $\begin{array}{l}64.4 \\
35.6\end{array}$ & $\begin{array}{l}80 \\
24\end{array}$ & $\begin{array}{l}76.9 \\
23.1\end{array}$ & 3.920 & $0.048 *$ \\
\hline $\begin{array}{l}\text { Residence } \\
\text { Rural } \\
\text { Urban }\end{array}$ & $\begin{array}{l}59 \\
43\end{array}$ & $\begin{array}{l}57.8 \\
42.2\end{array}$ & $\begin{array}{l}74 \\
30\end{array}$ & $\begin{array}{l}71.2 \\
28.8\end{array}$ & 3.998 & $0.046^{*}$ \\
\hline
\end{tabular}


Table (2): Distribution of the Studied Women According to their Obstetrical History $(\mathrm{n}=208)$

\begin{tabular}{|c|c|c|c|c|c|c|}
\hline \multirow[t]{2}{*}{ Past obstetric history } & \multicolumn{2}{|c|}{$\begin{array}{l}\operatorname{Cases}(\text { PTL) } \\
(\mathbf{n}=104)\end{array}$} & \multicolumn{2}{|c|}{$\begin{array}{l}\text { Control } \\
(n=104)\end{array}$} & \multirow[t]{2}{*}{$\mathbf{X}^{2}$} & \multirow[t]{2}{*}{$\mathbf{P}$} \\
\hline & No & $\%$ & No & $\%$ & & \\
\hline $\begin{array}{l}\text { Gravidity } \\
\text { Nulligravida } \\
\text { The rest } \\
\text { Primigravida } \\
2-3 \\
4+ \\
\end{array}$ & $\begin{array}{l}39 \\
\mathbf{N}=\mathbf{6 5} \\
35 \\
29 \\
1\end{array}$ & $\begin{array}{l}37.5 \\
\mathbf{6 2 . 5} \\
53.8 \\
44.6 \\
1.5\end{array}$ & $\begin{array}{l}14 \\
\mathbf{N}=\mathbf{9 0} \\
43 \\
47 \\
0\end{array}$ & $\begin{array}{l}13.5 \\
86.5 \\
47.8 \\
52.2 \\
0\end{array}$ & $\begin{array}{l}15.825 \\
2.106\end{array}$ & $\begin{array}{l}<0.001 * \\
0.349\end{array}$ \\
\hline \begin{tabular}{|l|} 
Number of abortion: \\
Not present \\
Present \\
1 \\
$4+$ \\
\end{tabular} & $\begin{array}{l}56 \\
(\mathbf{N}=\mathbf{4 8}) \\
31 \\
17 \\
0 \\
\end{array}$ & \begin{tabular}{|l}
53.8 \\
46.2 \\
64.6 \\
35.4 \\
0 \\
\end{tabular} & $\begin{array}{l}61 \\
(\mathbf{N}=\mathbf{4 3}) \\
32 \\
11 \\
0 \\
\end{array}$ & $\begin{array}{l}58.7 \\
41.3 \\
74.4 \\
25.6 \\
0 \\
\end{array}$ & $\begin{array}{l}0.488 \\
1.030\end{array}$ & $\begin{array}{l}0.485 \\
0.310\end{array}$ \\
\hline $\begin{array}{l}\text { Parity: } \\
\text { Nulliparous } \\
\text { Primipara } \\
2-3 \\
4+ \\
\end{array}$ & $\begin{array}{l}41 \\
32 \\
30 \\
1 \\
\end{array}$ & \begin{tabular}{|l}
39.4 \\
30.8 \\
28.8 \\
1 \\
\end{tabular} & $\begin{array}{l}17 \\
46 \\
41 \\
0 \\
\end{array}$ & \begin{tabular}{|l}
16.3 \\
44.2 \\
39.4 \\
0 \\
\end{tabular} & 15.148 & $0.002^{*}$ \\
\hline $\begin{array}{l}\text { Number of living children: } \\
\text { None } \\
\text { Yes } \\
\text { No. } \\
1 \\
2-3 \\
4+ \\
\end{array}$ & $\begin{array}{l}42 \\
62 \\
37 \\
27 \\
1\end{array}$ & $\begin{array}{l}40.4 \\
59.6 \\
56.9 \\
41.5 \\
1.5 \\
\end{array}$ & $\begin{array}{l}17 \\
87 \\
40 \\
43 \\
0\end{array}$ & $\begin{array}{l}16.3 \\
83.7 \\
48.2 \\
51.8 \\
0 \\
\end{array}$ & $\begin{array}{l}14.788 \\
2.624\end{array}$ & $\begin{array}{l}<0.001 * \\
0.269\end{array}$ \\
\hline
\end{tabular}




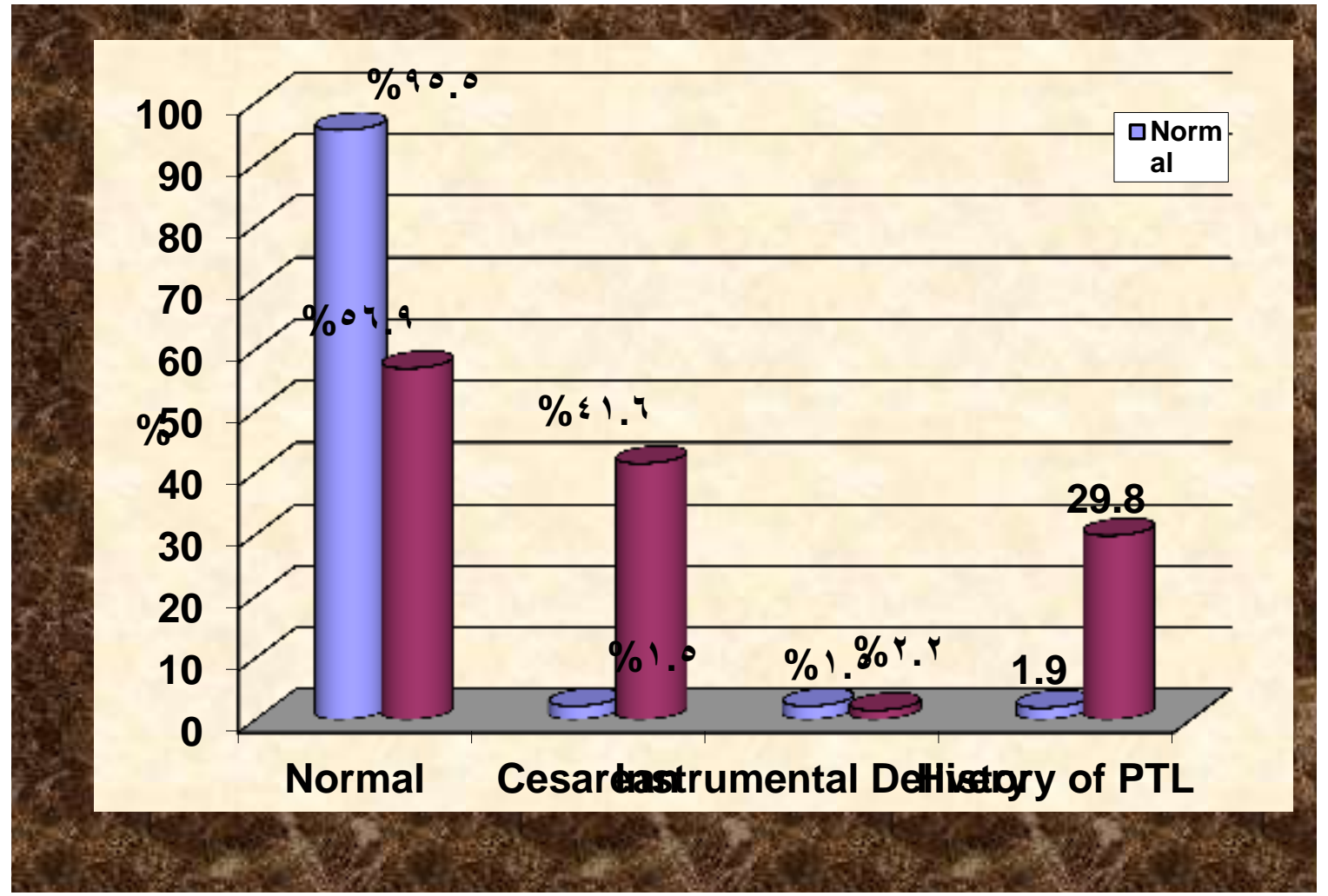

Figure (1): distribution of studied women according to the history of PTL and the mode of last delivery $(n=208)$.

Table (3): Distribution of the Studied Women According to their Life Style ( $n=208$ ).

\begin{tabular}{|c|c|c|c|c|c|c|}
\hline \multirow[t]{2}{*}{ Life style } & \multicolumn{2}{|c|}{\begin{tabular}{|l} 
Patients \\
$($ PTL $)$ \\
$(\mathbf{n}=\mathbf{1 0 4})$
\end{tabular}} & \multicolumn{2}{|c|}{$\begin{array}{l}\text { Control } \\
(\mathbf{n}=\mathbf{1 0 4})\end{array}$} & \multirow[t]{2}{*}{$\mathbf{X}^{2}$} & \multirow[t]{2}{*}{$\mathbf{P}$} \\
\hline & No & $\%$ & No & $\%$ & & \\
\hline $\begin{array}{l}\text { Passive smoking } \\
\text { Yes } \\
\text { No }\end{array}$ & $\begin{array}{l}70 \\
34\end{array}$ & $\begin{array}{l}67.3 \\
32.7\end{array}$ & $\begin{array}{l}56 \\
48\end{array}$ & $\begin{array}{l}53.8 \\
46.2\end{array}$ & 3.946 & $0.047 *$ \\
\hline $\begin{array}{l}\text { Excessive intake of coffee or tea } \\
\text { Yes } \\
\text { No }\end{array}$ & $\begin{array}{l}68 \\
36\end{array}$ & $\begin{array}{l}65.4 \\
34.6\end{array}$ & $\begin{array}{l}60 \\
44\end{array}$ & $\begin{array}{l}57.7 \\
42.3\end{array}$ & 1.300 & 0.254 \\
\hline $\begin{array}{l}\text { Exposure to violence } \\
\text { Yes } \\
\text { No }\end{array}$ & $\begin{array}{l}31 \\
73\end{array}$ & $\begin{array}{l}29.8 \\
70.2\end{array}$ & $\begin{array}{l}21 \\
83\end{array}$ & $\begin{array}{l}20.2 \\
80.6\end{array}$ & 2.564 & 0.109 \\
\hline $\begin{array}{l}\text { Exposure to stress } \\
\text { Yes } \\
\text { No }\end{array}$ & $\begin{array}{l}74 \\
30\end{array}$ & $\begin{array}{l}71.2 \\
28.8\end{array}$ & $\begin{array}{l}41 \\
63\end{array}$ & $\begin{array}{l}39.4 \\
60.5\end{array}$ & 21.179 & $<0.001 *$ \\
\hline $\begin{array}{l}\text { Having enough sleep } \\
\text { Enough } \\
\text { Not enough }\end{array}$ & $\begin{array}{l}40 \\
64\end{array}$ & $\begin{array}{l}38.5 \\
61.5\end{array}$ & $\begin{array}{l}86 \\
18\end{array}$ & $\begin{array}{l}82.7 \\
17.3\end{array}$ & 42.599 & $<0.001 *$ \\
\hline
\end{tabular}


Table (5): Distribution of the Studied Women According to Current Medical and Gynecological History $(\mathrm{n}=208)$

\begin{tabular}{|c|c|c|c|c|c|c|}
\hline \multirow[t]{2}{*}{ Medical and gynecological history } & \multicolumn{2}{|c|}{$\begin{array}{l}\text { Patients } \\
(n=104)\end{array}$} & \multicolumn{2}{|c|}{$\begin{array}{l}\text { Control } \\
(\mathrm{n}=104)\end{array}$} & \multirow[t]{2}{*}{$\mathbf{X}^{2}$} & \multirow[t]{2}{*}{$\mathbf{P}$} \\
\hline & No & $\%$ & No & $\%$ & & \\
\hline \multicolumn{7}{|l|}{ Diseases } \\
\hline Not present & 67 & 64.4 & 85 & 81.7 & 7.917 & $0.005^{*}$ \\
\hline Present & 37 & 35.6 & 19 & 18.3 & & \\
\hline \multicolumn{7}{|l|}{ Causes } \\
\hline Diabetes Mellitus & 7 & 6.7 & 1 & 1 & 4.680 & $0.031 *$ \\
\hline Renal Diseases & 6 & 5.8 & 4 & 3.8 & 0.420 & 0.517 \\
\hline Cardiovascular Disease & 5 & 4.8 & 3 & 2.9 & 0.520 & 0.471 \\
\hline Pre-eclamsia & 24 & 23.1 & 1 & 1 & 24.051 & $<0.001 *$ \\
\hline Thyroid disease & 0 & 0.0 & 4 & 3.8 & 4.078 & $0.043^{*}$ \\
\hline Vaginal infection & 17 & 16.3 & 9 & 8.7 & 2.813 & 0.093 \\
\hline Cervix incompetence & 4 & 3.8 & 3 & 2.9 & 0.148 & 0.701 \\
\hline
\end{tabular}

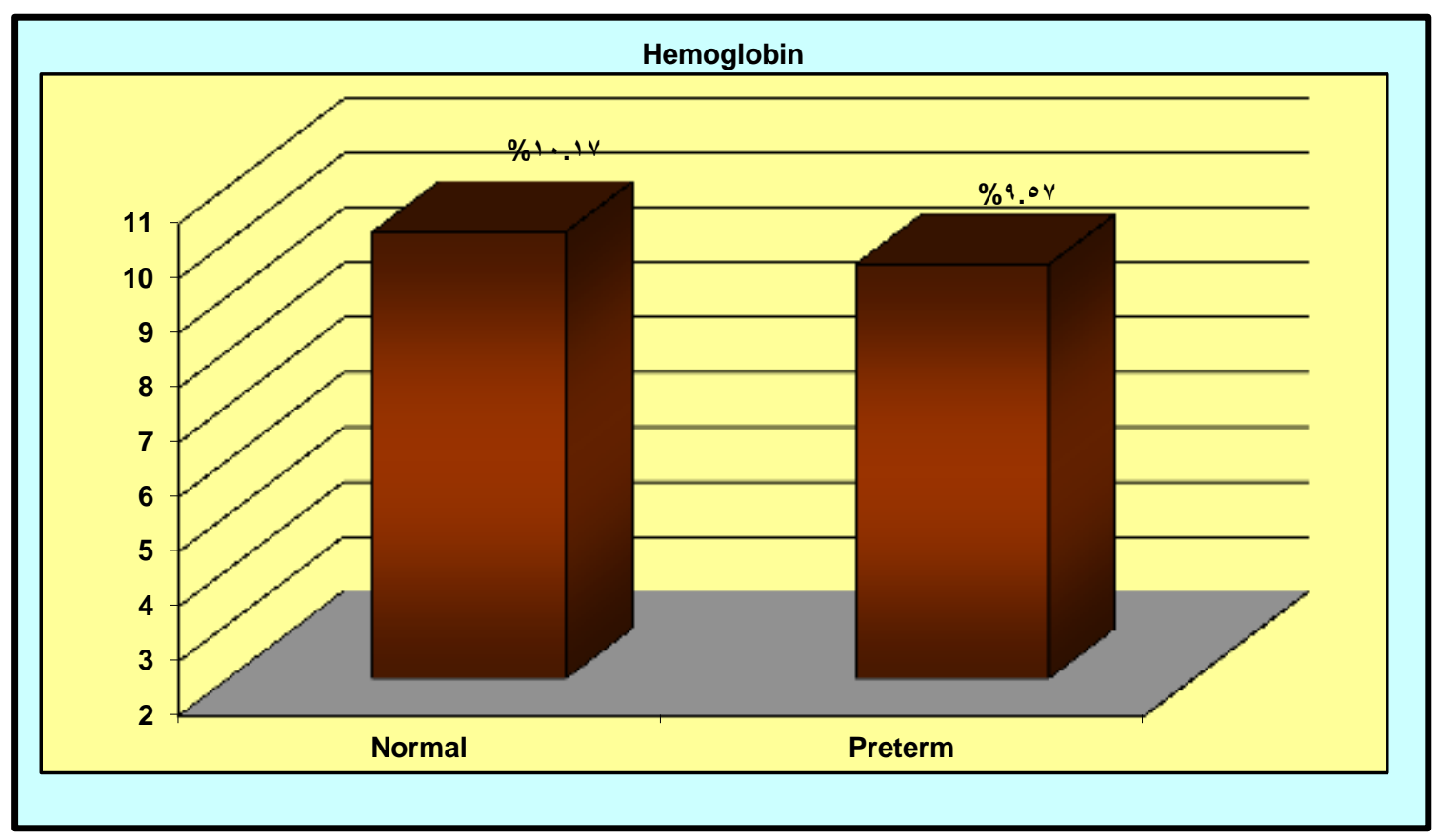

Figure (2): Distribution of the Studied Groups According to Hemoglobin level. 
Table (6): Distribution of the Studied Women According to the Clinical Features on Admission to the Hospital $(\mathrm{n}=208)$

\begin{tabular}{|c|c|c|c|c|c|c|}
\hline \multirow[t]{2}{*}{$\begin{array}{l}\text { Clinical features on admission } \\
\text { to the hospital }\end{array}$} & \multicolumn{2}{|c|}{$\begin{array}{l}\text { Patients } \\
(\text { PTL }) \\
(\mathbf{n}=\mathbf{1 0 4})\end{array}$} & \multicolumn{2}{|c|}{$\begin{array}{l}\text { Control } \\
(n=104)\end{array}$} & \multirow[t]{2}{*}{$\mathbf{X}^{2}$} & \multirow[t]{2}{*}{$\mathbf{P}$} \\
\hline & No & $\%$ & No & $\%$ & & \\
\hline Labor pain & 50 & 48.1 & 95 & 91.3 & 46.108 & $<0.001^{*}$ \\
\hline Premature rupture of membrane & 66 & 63.5 & 32 & 30.8 & 22.305 & $<0.001 *$ \\
\hline Vaginal Bleeding & 12 & 11.5 & 1 & 0.9 & \multirow{5}{*}{41.450} & \multirow{5}{*}{$<0.001 *$} \\
\hline Pre-eclamsia & 20 & 19.2 & 1 & 0.9 & & \\
\hline No fetal movement & 0 & 0.0 & 2 & 1.9 & & \\
\hline Early separation of placenta & 2 & 1.9 & 0 & 0 & & \\
\hline watery fluid after sexual intercourse & 3 & 2.8 & 0 & 0 & & \\
\hline
\end{tabular}

Table (9): Distribution of the Studied Women According to Apgar score at the $1^{\text {st }}$ and the $5^{\text {th }}$ Minute and Birth Weight $(\mathrm{n}=208)$

\begin{tabular}{|c|c|c|c|c|c|c|}
\hline \multirow{3}{*}{ Apgar score } & \multicolumn{4}{|c|}{ Groups } & \multirow{3}{*}{$\mathbf{X}^{2}$} & \multirow{3}{*}{$\mathbf{P}$} \\
\hline & \multicolumn{2}{|c|}{$\begin{array}{l}\text { Patients } \\
\text { (PTL) } \\
(\mathbf{n}=104)\end{array}$} & \multicolumn{2}{|c|}{$\begin{array}{l}\text { Control } \\
(n=104)\end{array}$} & & \\
\hline & No & $\%$ & No & $\%$ & & \\
\hline $\begin{array}{l}\text { Apgar score at } 1 \text { minute } \\
<3 \\
4-6 \\
7+ \\
\end{array}$ & $\begin{array}{l}4 \\
100 \\
0\end{array}$ & $\begin{array}{l}3.8 \\
96.2 \\
0\end{array}$ & $\begin{array}{l}0 \\
87 \\
17\end{array}$ & $\begin{array}{l}0 \\
83.7 \\
16.3\end{array}$ & 21.904 & $0.000 *$ \\
\hline Range & \multicolumn{2}{|l|}{$2-6$} & \multicolumn{2}{|l|}{$4-7$} & \multirow{2}{*}{$\mathrm{t}=15.164$} & \multirow{2}{*}{$0.000 *$} \\
\hline Mean \pm SD & \multicolumn{2}{|c|}{$4.43 \pm 0.68$} & \multicolumn{2}{|c|}{$5.88 \pm 0.69$} & & \\
\hline $\begin{array}{l}\text { Apgar score at } 5 \text { minutes } \\
<3 \\
4-6 \\
7+ \\
\end{array}$ & $\begin{array}{l}0 \\
72 \\
32\end{array}$ & $\begin{array}{l}0 \\
69.2 \\
30.8\end{array}$ & $\begin{array}{l}0 \\
3 \\
101\end{array}$ & $\begin{array}{l}0 \\
2.9 \\
97.1\end{array}$ & 99.277 & $0.000 *$ \\
\hline Range & \multicolumn{2}{|l|}{$4-8$} & \multicolumn{2}{|l|}{$6-9$} & \multirow{3}{*}{$\mathrm{t}=16.490$} & \multirow{2}{*}{$0.000 *$} \\
\hline Mean \pm SD & \multicolumn{2}{|c|}{$6.19 \pm 0.75$} & \multicolumn{2}{|c|}{$7.87 \pm 0.71$} & & \\
\hline \multicolumn{6}{|l|}{ Birth weight } & \\
\hline Range & \multicolumn{2}{|c|}{$0.80-5.0$} & \multicolumn{2}{|c|}{$0.75-5.0$} & \multirow{2}{*}{$t=21.686$} & \multirow{2}{*}{$0.000 *$} \\
\hline Mean \pm SD & \multicolumn{2}{|c|}{$1.38 \pm 0.58$} & \multicolumn{2}{|c|}{$2.90 \pm 0.41$} & & \\
\hline
\end{tabular}




\section{DISCUSSION}

Worldwide, nearly 600,000 women (15-49 years) die every year as a result of complications arising from pregnancy and childbirth. The risk of a woman dying during such period is about one in six in the poorest parts of the world compared with about one in 30000 in Northern Europe. Such a discrepancy poses a huge challenge in Egypt for meeting the fifth Millennium Development Goal to reduce maternal mortality by 75\% between 1990 and 2015 (Sayed et al., 2010).

Significant progress has been made in the care of premature infants, but not in reducing the prevalence of preterm birth (Goldenberg et al., 2008). In the United States, there has been a $21 \%$ rise in the rate of preterm births since 1990, which peaked in 2006 with $12.8 \%$ of all 4 million annual live births born at less than 37 weeks of gestation (Robert, 2007). The incidence in Europe and other developed countries lies between 5-9\% (Goldenberg et al., 2008). East Asian and Hispanic women typically have a low pre-term birth rate. However, the incidence of preterm birth continues to rise. Part of this escalation is due to the increased indicated preterm delivery of artificially conceived multiple pregnancies, which account for 15-20\% of all pre-term births (Goldenberg et al., 2008).

Approximately $45-50 \%$ of preterm births are idiopathic, $30 \%$ are related to preterm rupture of membranes (PROM) and another $15-20 \%$ is attributed to medically indicated or elective preterm deliveries. Estimation of preterm birth rates and, ideally, their proper categorization (e.g. spontaneous versus indicated) are essential for accurate determination of global incidence in order to inform policy and programmers on interventions to reduce the risk of premature labor and delivery (Pennell, 2007).

Many factors are known to be associated with preterm labor as; previous preterm delivery, smoking, uterine bleeding, infection and stress (Edmund, 2014). Early diagnosis and appropriate management improve both maternal and perinatal outcomes (Kiondo et al., 2008). Therefore, the present study was conducted to determine the risk factors associated with preterm labor. The study was carried out on two groups of women, "one diagnosed with PTL being hospitalized or none hospitalized before delivery and one with normal vaginal delivery" recruited from the labor unit at Belqas general Hospital. 
Among the factors that may be associated with preterm labor are the sociodemographic characteristics of the mother such as; age and educational level. In the present study, women who had PTL were significantly more likely to be younger than $<20$ years of age or older than 30 years compared with normal vaginal labor. This finding was consistent with Omer (2004); Ahmed (2008) who found significant association between the preterm labor and the advanced maternal age. In addition, Ahmed (2008) showed that almost a half of the subjects were at a higher risk of preterm because of their young or old age. However, their proportion was much higher than that of the present study; such discrepancy may be due to different cultures, which allow teenage pregnancies in developed countries. Rouget et al. (2013) reported that young maternal age (<20years) wasn't a risk factor for preterm birth, although older age >30 years was associated with an increased risk of spontaneous preterm birth. In this regard Abu Hamed (2007) in Gaza strip found a relationship between age >30 years and risk of preterm birth; Newburn \& Onyskiw (2005); Zhang et al. (2012) clarified that association by the presence of confounding factors such as pre-existing medical problems, it is well Known that maternal age $>30$ years is linked to the occurrence of medical complication of pregnancy.

In this respect Astolfi \& Zonta (2002) found in a population sample of Italian women a 64 percent increased odds of preterm delivery among mothers 35 years of age or older compared with that among mother less than 35 years of age when education, birth order, and fetal gender were controlled for. The risk was particularly striking among mothers over 35 years of age delivering their first-born child. The reasons for the increased risk for preterm delivery among older women are not known.

Concerning the level of education and job status the present study revealed that the majority of women in the two groups had secondary school education and were housewives with no statistical significant difference. In the same line, Ananth et al. (2006) concluded that low educational level and unemployment of all household members was associated with twice the risk of very preterm birth. On the contrary the study of Kiondo et al. (2008) in Uganda revealed that, the patients who were employed were associated with twice the risk of PTL with bleeding, since they spend less time resting which may predispose them to hemorrhage because bed rest is one way of managing preterm labor. 
The present study analysis of obstetrical history showed that the nulligravida and primigravida women were more likely to have preterm labor compared to the control group. Conversely Copper et al. (2001); Baldor, (2001); Zhang et al. (2012) found that, the frequency of multiparaous women was significantly higher in the group of women with preterm labor $(\mathrm{p}<0.001)$. While nulliparaous was present in $39.4 \%$ of women who had preterm labor compared to $16.3 \%$ of normally vaginal delivery group. Similarly, Ahmed (2008) found that women with multipara had higher risk for preterm labor development with statistical significance. Additionally, Cardozo et al. (2004) stated that $35 \%$ of his study had the risk for preterm labor because of being multipara. These findings disagree with Samim \& Wafaa (2006) in Iraq who reported that no significant association was observed between PTB and parity. The difference between the above mentioned studies and the present one might be due to differences in the size of the sample and its characteristics.

According to the present study findings, patients who had previous cesarean section were significantly associated with an increased risk of preterm labor. Most studies have reported an association between previous cesarean section and preterm labor. The American National Vital Statistics Report (2002) that $30 \%$ of their study samples had history of CS. Similar finding was reported by Saparito et al. (2003); Grisaru et al. (2004) who found a relation between cesarean birth and preterm labor with percentage of cesarean birth (52\% and $70 \%$ respectively).

Abu Hamad (2007) reported that a significant positive relationship between the previous history of CS and having preterm birth. There is a consensus in the literature about the role of CS delivery as a contributing factor for preterm birth. Bettiol et al. (2000) study in Brazil, found that CS was the main contributor to the increasing rate of preterm birth rate. They noted that there is a relationship between CS and preterm delivery. On the other hand, Basso \& Baird. (2003); Omer (2004); Ahmed (2008) found that the history of previous cesarean section was significantly different by lower percentage $22 \%, 12.5 \%$ respectively.

More than one fourth of the PTL women had history of previous PTL. This result is in accordance with Abu Hamad, (2007); Zhang et al. (2012) who noticed a positive association between the history of a previous preterm birth with a more than 5-fold 
increased risk of preterm birth and the chance of having preterm birth was increased by increasing number of previous preterm births. Moreover, Hasaneen (2004) have put into evidence that women with a history of preterm labor have a 2.2 to 5 times risk of having another preterm delivery.

According to a recent study carried out by Bloom et al. (2001) the risk of recurrence of preterm birth accounted for $10 \%$ of preterm births. Also, Copper et al. (2001) reported that nearly similar percentage (27\%) of her sample had history of previous preterm labor. On the contrary, the study of Ahmed (2008) in Damanhur was 18\% less than the present study. This discrepancy may be attributed to different type and cause of preterm labor.

The present study has revealed controversial results for an association between smoking and PTL, this finding agree with Schoman (2005); Samim \& Wafaa (2006) in Iraq. And disagree with, Moutquin (2003) who found a significant association. Meanwhile, exposure to smoking (passive smoking) was a risk factor for PTL because it is common in our social setup. This finding is consistent with Ahmed (2008) who have reported that, women who had preterm labor had higher rate of passive smoking, while Hasaneen (2004) found a lower percentage of smoking (between $15 \%$ and $29 \%$ ).

As for the psychological or social stress the present study shows that women experiencing high levels of psychological or social stress are at increased risk of preterm birth. Stress, anxiety and other psychological disturbances have been suspected as risk factors for PTВ Moutquin (2003); Da Silva (2003); Savitz, (2004); Zhu et al. (2010). It is a common belief in Egypt communities that PTL is associated with anxiety and severe fright, and in the last two years stressful life events have increased in this country. The study confirmed a significant association between stress and PTL. It has been claimed that stress and anxiety increases corticotrophin-releasing hormones and may ultimately result in increased uterine contractility. Stress also increases cytokine production, which may independently lead to PTB or increase susceptibility to infection and subsequent PTB. These findings agree with Zhang et al. (2012); Edmund et al. (2014) they said that stress is a risk for preterm labor (generally <2-fold) even after adjustment for the effects of socio demographic, medical, and behavioral risk factors. Furthermore, exposure to objectively stressful conditions, such as housing instability and severe material hardship, has also been associated with preterm birth. 
Concerning fetal outcome, the present study demonstrates significantly lower Apgar scores at the first and fifth minutes in the patients group $(\mathrm{p}=0.000)$. Meanwhile, they were more likely to have low birth weight $($ Mean \pm SD $1.38 \pm 0.58$ versus $2.90 \pm 0.41$ respectively). This findings was consistent with Hasaneen (2004) in Zagazig who found that the mean Apgar scoring after 1 and 5 minutes among the study group was significantly lower than that of the control group $(\mathrm{p}=0.000)$ also this finding is congruent with what is known about the association between preterm labor and low Apgar scoring (Weinberger et al., 2000). Recently, Bhutia et al. (2011) have found the significant difference in neonatal APGAR score $\leq 7$ in 1 minute ( $p$ value $=0.006$ ) whereas there were no differences in APGAR score $\leq 7$ in 5 minutes, low birth weight infant. Reasons for variations among studies might be due to the fetal and maternal conditions during pregnancy as well as prenatal diagnosis and selected management at the time of delivery.

\section{CONCLUSION:}

Based on study findings, it can be concluded that:

More than one third of PTL women were nulligravida and nulliparas. Higher percentage of them was exposed to violence and stress, passive smoking, medical and gynecological problems. The study also shows that women in the PTL group were more likely to have premature rupture of membranes, vaginal bleeding and anemia. Almost two thirds of them were exposed to CS delivery and half of them suffered from postnatal complication as post partum hemorrhage and infection. In addition, Preterm labor had adverse effects on fetal birth outcome. It also resulted in lower Apgar score, low birth weight.

\section{RECOMMENDATIONS:}

\section{Based on the results of the present study, the following recommendations were suggested:}

Early diagnosis of preterm labor, identification of risk factors, adopting recent modalities of diagnoses and management in appropriate setting and with adequate resources may help in better outcome by reducing the fetal-maternal complications, efforts should be made to reduce the rates of operative deliveries, because there is a greater likelihood of preterm labor in scarred uterus in a subsequent pregnancy. 


\section{REFERENCES}

Abu Hamad, K.H., Abed, Y. and Abu Hamad, B. (2007): Risk factors associated with preterm birth in the Gaza strip hospital- based case- control study, 13(5).

Ahmed, G.S.H., Nour S.A (2008): Risk Factors That Lead To Preterm Labor. Master Thesis, Faculty of nursing. Tanta University

Al-Jawadi, T.A. (1998): Identification of the high risk pregnancy and its outcomes: a cohort study. Mosul Medical College. University of Mosul, M.Sc. Thesis: P.p.29-32.

Ananth, C.V. and Vintzileos, A.M. (2006): Epidemiology of preterm birth and its clinical subtypes. J Matern Fetal Neonatal Med; 19: 773-82.

Astolfi, P. and Zonta, L.A. (2002): Delayed maternity and risk at delivery. Paediatric and Perinatal Epidemiology. 2002;16(1):67-72.

Baldor S. (2001): The preterm prediction study. Spontaneous preterm birth and multipara. Am J Obest Gynecol, P.p. 1286-1292.

Basso, O. and Baird, D.D. (2003): Infertility and preterm delivery, birthweight, and Caesarean section: a study within the Danish National Birth Cohort. Human Reproduction.18, (11): P.p. 2478-2484.

Bhutia, P.C., Lertbunnaphong, T. and Wongwananuruk, T. (2011): Prevalence of Pregnancy with Placenta Previa in Siriraj Hospital. Siriraj Med J; 63 (6):191-196.

Bloom, S.L. (2001): Recurrence of preterm birth in singleton and twin pregnancies. Obstetrics and Gyneacology, 98(3): P.p. 379-85.

Bettiol, H. (2000): Factors associated with preterm birth in southeast Brazil: a comparison of two birth cohort born 5 years apart pediatric and prenatal epidemiology, 14 (1): P.p. 30-38.

Chowan Paiboons (2010): Clinical practice guidelines; management of preterm `labor. Department of obstetrics Gynecology, faculty of Medicine, Siriraj Hospital, Mahidot university.

Copper, R., Goldenberg, R. and Swain, M. (2001): The preterm prediction study: maternal stress is associated with spontaneous preterm birth at less than thirty five weeks gestation. American Journal of obstetrics and Gynecology; P.p. 1286 -1292.

Da Silva, A.A., Simoes, V.M., Barbieri, M.A., Bettiol, H., Lamy-Filho, F., Coimbra, L.C. and Alves, M.T. (2003): Young maternal age and preterm birth. Paediatr Perinat Epidemiol, 17(4):332-339.

Edmund F Funai, Charls J Lockwood and Vanessa A Barss (2014):Patient information Preterm labor(Beyond and the Basics). This topic last updates: Mar12 2014. 
Goldenberg, R.L., Culhane, J.F., Iams, J.D. and Romero, R. (2008): "Epidemiology and causes of preterm birth". The Lancet 371 (9606): P.p. 75-84 doi: 10.1016/S01406736(08)60074-4 pmid: $\underline{18177778 .}$.

Grisoru, L. (2004): Effective care in pregnancy and childbirth. Oxford University press.

Hasaneen, N. (2004): Predictions of preterm labor among pregnant women at risk in Zagazig university Hospital, PH.D thesis, Zagazig University, Faculty of Nursing.

Kiondo, P., Wandabwa, J. and Doyle, P. (2008): Risk factors for Placenta Praevia Presenting with Severe Vaginal Bleeding in Mulago hospital, Kampala, Uganda. African Health Science; 8(1): 44-49.

Moutquin, J.M. (2003): Socio-economic and psychological factors in the management and prevention of preterm labor. (110): P.p. 56-60.

National Premmie Foundation (2014): Risk factors \& causes of premature birth. Available at: http://www.prembaby.org. . Accessed Nov. 15, 2014

Newburn, C.V. and Onyskiw, J.E. (2005): Is Older Maternal Age a Risk Factor for Preterm Birth and Fetal Growth Restriction?

Omer, A., Ali S. A. (2004): Developing Nursing Guidelines for high risk pregnanc, Msc thesis. Alexandria University, Faculty of Nursing.

Pennell, C.E., Jacobsson. B., Williams, S.M. Buus, R.M., Muglia, L.J. and Dolan, S.M. (2007): Genetic epidemiologic studies of preterm birth: guidelines for research. Am J Obstet Gynecol; 196: 107-18 doi: 10.1016/j.ajog.2006.03.109 pmid: 17306646.

Robert, L., Goldeberg and Jennifer F. (2007): Low birth weight in the United States1,2,3.American society for clinical Nutrition: updated by The American Journal of clinical nutrition (2014): Jan (372)MD20814.

Ricci, S. and Kyle, T (2009): Placenta Previa, Nursing Management of Pregnancy at Risk: Pregnancy-Related Complications, in Maternity and Pediatric Nursing Book, Chapter19, Lippincott Williams \& Wilkins; pp560:564

Rouget, F., Lebreton, J., Kadhel, P., Monfort, C., Bodeau-Livinec, F., Janky, E., Multigner, L. and Cordier S. (2013): Medical and sociodemographic risk factors for preterm birth in a French Caribbean population of African descent.

Samim, A. Al-Dabbagh and Wafa, Y. Al-Taee (2006): Risk factors for pre-term birth in Iraq: a case-control study. Available at: http://www.biomedcentral.com/1471-2393/6/13

Saporita K. (2003): Prevention of preterm birth. Semin perinatal,London; P.p. 295-301.

Savitz, D.A., Kaufman, J.S., Dole, N. (2004): Poverty, education, race, and pregnancy outcome. Ethnicity and Disease, 14: P.p. 322-329.

Sayed, H.A., El Araby, A. and Hamed, R. (2010): Egypt Progress toward Achieving The Millennium Development Goals (MDGs) - UNDP in Egypt. available at: 
www.undp.org.eg/Portals/0/MDG/ 2010\%20MDGR _ English_R5 accessed at October, 18,2012

Schoeman, J., Grove, D.V. and Odendaal, H.J. (2005): Are domestic violence and excessive use of alcohol risk factors for preterm birth? J TropPediatr 2005, 51(1): P.p. 49-50.

Simhan HN and Caritis SN (2007): "Prevention of Preterm Delivery". New England Journal of Medicine; 357 (5): P.p. 477-487.

Society of obstetricians and Gynecologists of Canada SOGC (2013): Preterm labour. tel:(800) 581-2418 or (813) 730-4492.

Wasiela, M., Krzeminski, Z., Hanke, W. and Kalinka, J. (2003): Association between genital mycoplasmas and risk of preterm delivery. Med Wieku Rozwoj, 7(3 suppl 1): P.p. 211-216.

Weinberger, B., Anwar, M., Hegyi, T. and Hiatt, M. (2000): Antecedents and Neonatal Consequences of Low Apgar Scores in Preterm Newborns. A Population Study, Arch Pediatr Adolesc Med.; 154(3):294-300.

World Health Organization. Reproductive Health and Research (2010): Available at URL: whqlibdoc. who.int/hq/2009/WHO_RHR_09.02_eng.pdf. Last accessed on June 2010 .

Zhang, Y.P., Liu, X.H., Gao, S.H, Wang, J.M., Gu, Y.S., Zhang, Y.J., Zhou, X. and Li, X.Q. (2012): Risk Factors for Preterm Birth in Five Maternal and Child Health Hospitals in Beijing. PLoS ONE 7(12): e52780. doi:10.1371/journal.pone.0052780

Zhu, P., Tao, F.B., Hao, J.H., Sun, Y. and Jiang, X.M. (2010): Prenatal life events stress: implications for preterm birth and infant birthweight. Am J Obstet Gynecol 203: 34.e1-8. doi: 10.1016/j.ajog.2010.02.023. 


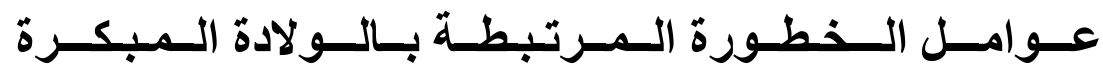 \\ أ.د / سناءعلى نور- د/ منار فتحى هييه- م/ رشا عوض ذكى على}

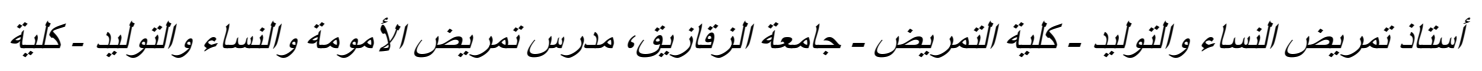

التمريض - جامعة بورسعيد، بكالوريوس تمريض- جامعة الإسكندرية

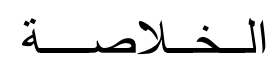

الولادة المبكرة واحدة من أهم مشاكل الحمل حيث تسبيت بنسبة كبيرة فى وفيات الأمهات وحديثى

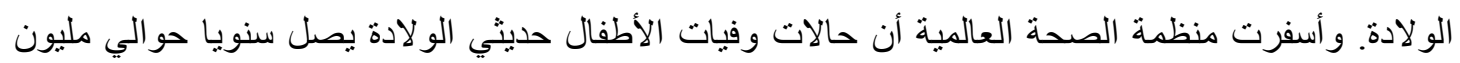
نتيجة مضداعفات الولادة المبكرة.هدف هذه الدراسة هو تحديد عوامل الخطورة المرتبطة بالولادة المبكرة. أجريت هذه الدراسة ذات الثواهد في مستشفى بلقاس العام واشنملت علي 208 امر أه حامل، 104 امر أة وضعن حملهن قبل الآوان،104 شاهدة وقد جمعت تللك المعلومات عن طريق استمارة استبيان المقابلة

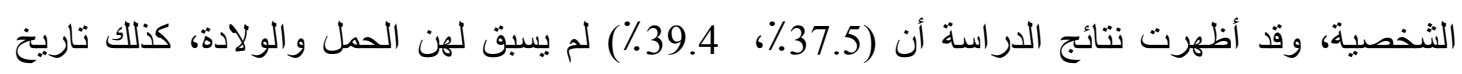

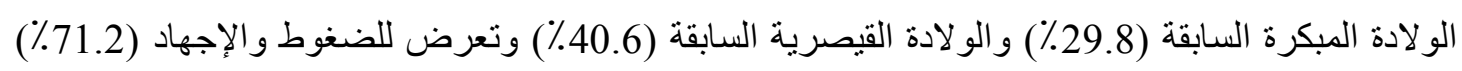

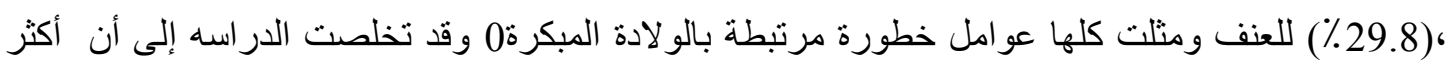

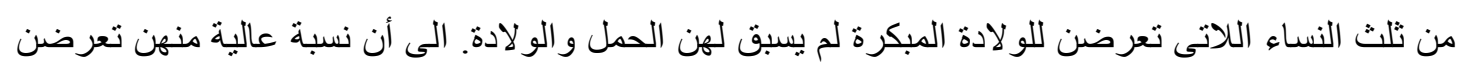

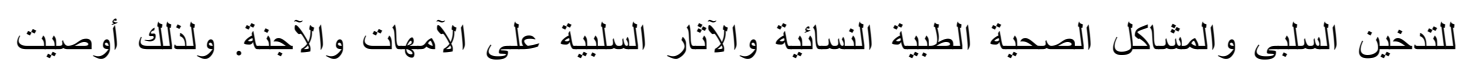

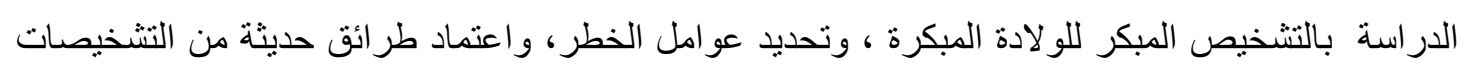

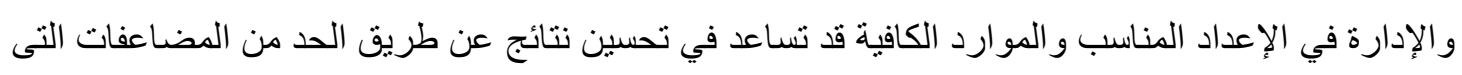
قد تحدث للأمهات وحديثي الو لادة. الكلمات الإسترشادية : الو لادة البكره ، عو امل الخطوره ، العلاج . 